\title{
Natural habitats uncovered? - Genetic structure of known and newly found localities of the endangered bitterling Pseudorhodeus tanago (Cyprinidae)
}

\author{
Kenji Saitoh', Noriyasu Suzuki ${ }^{2}$, Masumi Ozaki ${ }^{3}$, Kazuhiro Ishii ${ }^{4}$, Tetsuya Sado ${ }^{5}$, \\ Takahiro Morosawa ${ }^{6}$, Takatoshi Tsunagawa ${ }^{7}$, Masaru Tsuchiya ${ }^{8}$
}

I National Research Institute of Fisheries Science, Japan Fisheries Research and Education Agency, Fukuura 2-12-4, Kanazawa, Yokohama 236-8648, Japan 2 Chiba Biodiversity Center, Natural History Museum \& Institute, Chiba, Aoba 955-2, Chuo, Chiba 260-8682, Japan 3 Chiba Prefectural Fisheries Research Center, Usuidai 1390, Sakura, Chiba 285-0866, Japan 4 Ibaraki Prefectural Government, Kasahara 978-6, Mito, Ibaraki 310-8555, Japan 5 Natural History Museum \& Institute, Chiba, Aoba 955-2, Chuo, Chiba 2608682, Japan 6 Japan Wildlife Research Center, Kotobashi 3-3-7, Sumida, Tokyo 130-8606, Japan 7 Tochigi Prefectural Fisheries Experimental Station, Sarado 2599, Ohtawara, Tochigi 324-0404, Japan 8 Ibaraki Nature Museum, Osaki 700, Bando, Ibaraki 306-0622, Japan

Corresponding author: Kenji Saitoh (ksaitoh@affrc.go.jp)

Academic editor: S. Lengyel | Received 31 October 2016 | Accepted 3 March 2017 | Published 9 March 2017

http://zoobank.org/4AEE22C2-58A5-4362-A53C-23C217AD5109

Citation: Saitoh K, Suzuki N, Ozaki M, Ishii K, Sado T, Morosawa T, Tsunagawa T, Tsuchiya M (2017) Natural habitats uncovered? - Genetic structure of known and newly found localities of the endangered bitterling Pseudorhodeus tanago (Cyprinidae). Nature Conservation 17: 19-33. https://doi.org/10.3897/natureconservation.17.10939

\begin{abstract}
Overuse of natural resources by humans is a major threat to biodiversity. Overuse often involves species of economic or esthetic value, and fish are a typical example for a group that is exploited both for economic reasons (for human consumption) and for esthetic reasons (e.g. by aquarists). Pseudorhodeus tanago (Tanaka, 1909) (formerly known as Tanakia tanago) is a small colorful but legally protected (fishing, keeping and transfer are banned) bitterling fish distributed around Tokyo, Japan. Whereas it is critically endangered and more and more habitat loss has occurred, at least four stocks have been newly found during the last decade. To explore whether emergence of these newly found habitats is a consequence of incomplete survey, we genotyped mitochondrial cytochrome b sequence of $P$. tanago from 17 localities and an illegal home aquarium. Populations known by the past extensive survey (13 localities) showed geographically structured population genetic characteristics. Population-specific haplotypes were common indicating past divergence and bottleneck events. Four (north, \{center + west $\}$, south_1, south_2) or five
\end{abstract}

Copyright Kenji Saitoh et al. This is an open access article distributed under the terms of the Creative Commons Attribution License (CC BY 4.0), which permits unrestricted use, distribution, and reproduction in any medium, provided the original author and source are credited. 
(north, center, west, south_1, south_2) geographic groups were detectable as for these known localities. On the other hand, newly found stocks were polymorphic and showed identical haplotypes from distant known localities. If we assume historical basis of distribution and genetic characteristics of these newly found stocks, it must be a series of unlikely geological events and haplotype sorting. We discuss potential issues posed by these questionable stocks.

\section{Keywords}

Bottleneck, bucket biology, conservation genetics, fish dumping, home aquarium, phylogeography, poaching, satoyama, Tanakia tanago

\section{Introduction}

Overuse of organisms by hunting or fishing for trade or esthetic purposes is one of the biggest threats to biodiversity. Controlling these activities is fundamental for ensuring the persistence of endangered organisms, particularly those that have traits attractive to humans. Alerts to poaching are thus necessary on those organisms legally protected. Not only tusks of elephants and rhinos but beautifully colored bodies of fish as well have attracted violators. The red list of Japanese brackish and freshwater fish (Ministry of the Environment, Japan 2015) acknowledges 39 species out of 168 of endangered and vulnerable categories have threats of overfishing in connection with home aquarium. Inversely, unauthorized fish release also threatens the integrity of natural fish population structures. A big source of invasion of alien freshwater fish is fish dumping from home aquaria (Lintermans 2004, Gertzen et al. 2008, Fuller et al. 2013, Ishikawa and Tachihara 2014). Poaching and dumping of endangered and protected fish, if any, disturb conservation programs and policy making and ultimately threat that species.

Pseudorhodeus tanago (Tanaka, 1909) (formerly known as Tanakia tanago transferred to the new genus, Chang et al. 2014) is a colorful small bitterling fish endemic to Japan with a limited geographic range around Tokyo. Habitats of $P$. tanago are in small water bodies such as ditches or ponds with spring water in hills (Nakamura 1969, Mochizuki 1997, Maita 2002, Ishinabe 2014). These habitats link with traditional agricultural landscape known as 'satoyama'. Traditional farming activities have maintained ditches, ponds and vegetation around waters in farmlands in hills (Kobori and Primack 2003), and thus maintained habitats of P. tanago. However, because of heavily populated and highly developed areas around its habitats, $P$. tanago is critically endangered. Urbanization accompanying change of farming style gives rise to habitat loss (Mochizuki 1997, Ishinabe 2014). Agency for Cultural Affairs, and Ministry of the Environment, Japan have endorsed this bitterling as a legally protected species (Ministry of the Environment, Japan 2015). Fishing, keeping and transfer of $P$. tanago are banned. Since around 1970, conservation measures of $P$. tanago have been taken under local bases including extensive search for habitats, development of ex situ breeding techniques, protected area enclosure, mitigation of civil engineering activities (Tochigi Prefectural Fisheries Experimental Station 1973, Akiyama et al. 1994, Mochizuki 1997, Kubota et al. 2010, Ishinabe 2014). A national breeding program for the 
protection of the species began in 1995, which included ex situ breeding and habitat restoration (Agency of Environment, Japan et al. 1995).

Records of 45 localities of $P$. tanago habitats were established as part of an extensive survey (Tanaka 1909, Nakamura 1969, Maita 2002, Ishinabe 2014, present report) (Fig. 1a). Some of the localities have been kept secret by authorities because of risks of poaching. By around 2000, most known habitats were lost, and further local extinction has occurred in these days in spite of conservation measures (Fig. 1b). Many populations have undergone habitat degradation to decline to ca. 1/100 in a few years, and in an extreme case the population is vanishing in the final remnant habitat of a short $(<100 \mathrm{~m})$ stretch of a small (ca. $60 \mathrm{~cm}$ wide) stream (Mochizuki 1997).

From the habitat characteristics of $P$. tanago, confined and scattered among headwaters of fine branching dales in agricultural landscape on hill terrains, we assume geographically structured population genetic characteristics of this species. Kubota et al. (2010) outlined geographic population structure of this species, but lack of localities from southern part of its geographic range and usage of questionable specimens obscured clear-cut geographic structure. Analysis of geographic population structure of this critically endangered fish with habitat loss based on specimens from reliable sources is necessary for setting up conservation programs (Waples and Gaggiotti 2006).

Whereas more and more local populations have been lost recently, P. tanago were newly found in a few localities in the last decade ('newly found' locality or stock hereafter) (Fig. 1b, hatched areas). Are these newly found stocks are simply because of incomplete survey of distribution? The aims of this study were to delineate geographical genetic structure of $P$. tanago and to identify symptom of disturbance, if any, in this structure by an analysis of genotypes of 80 individuals from 18 populations or stocks. Four of them are from newly found localities, one from an illegal home aquarium, and the others are from localities previously known by the past extensive survey ('known' localities or populations hereafter).

\section{Materials and methods}

Pseudorhodeus tanago from 13 known localities collected from 1993 through 2013 (55 individuals), four newly found stocks collected from 2010 through 2014 (22 individuals), and three individuals seized from an illegal home aquarium were materials of this research (Table 1, Fig. 1b). Fishes from two out of the 13 known localities were of ex situ preserved stock extinct in the wild in early 1990s (\#8) and late 1970s (\#10). Habitat characteristics of the collecting localities were identical to descriptions in literatures (Nakamura 1969, Mochizuki 1997, Maita 2002) except for two newly found localities $(\# 14,17)$ where civil engineering activities including straight cut of channels with concrete enforcement have suffered their habitats.

Extraction of DNA was done from fin clips with QuickGene DNA Tissue kit on QuickGene-810 (Kurabo, Neyagawa, Japan). PCR primers were L14695 on the L-strand (AATTYTTGCTCRGACTCTAACC) and H15910 on the H-strand 


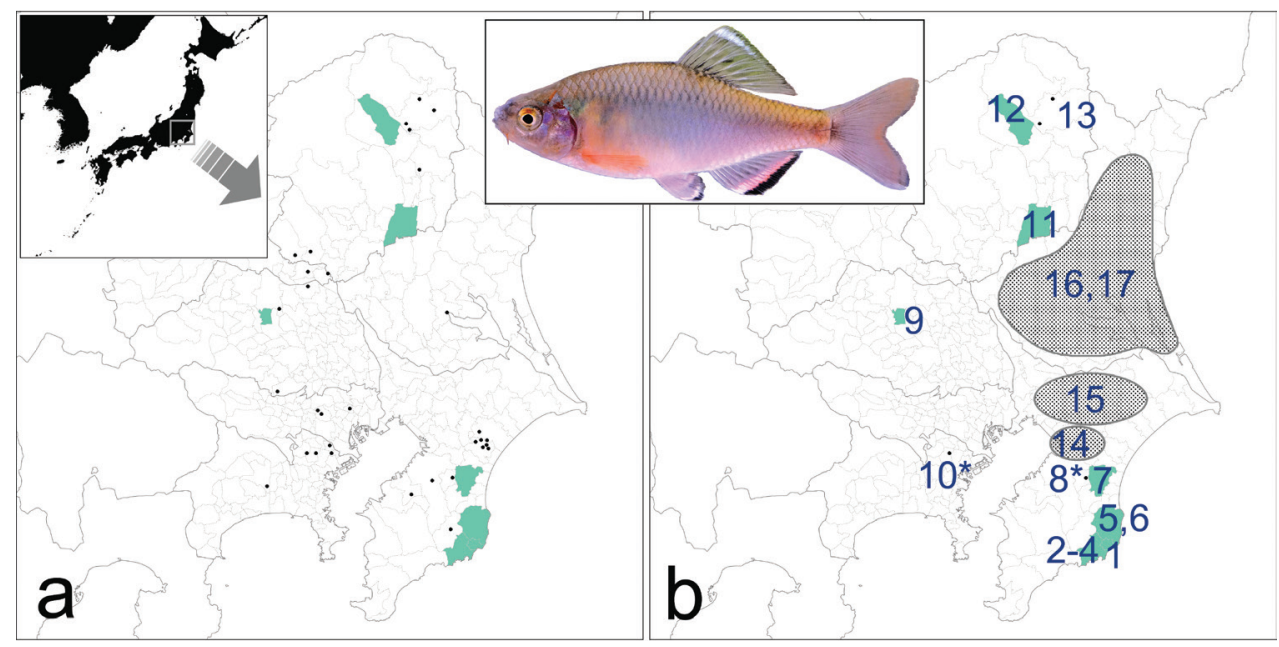

Figure I. Past (a) and present (b) geographic distribution of Pseudorhodeus tanago. Dots indicate records of presence of the bitterling. Light blue painted areas contain one to three localities from which specimens of the present report came. Exact places of these localities are kept secret by authorities to protect from poaching. Numbers on map b stand for localities of samples listed in Table 1. Asterisks indicate extinction in the wild and specimens came from ex situ preserved stocks. Habitats \#14-17 in hatched areas (exact places are kept secret by authorities) are newly found. Hatched areas thus do not represent exact geographic ranges.

Table I. Localities and specimens used in this study.

\begin{tabular}{c|c|c|c}
\hline$\#$ & Locality & Collecting date, year & Number of individuals \\
\hline 1 & Onjuku, Chiba & Dec. 19, 2012 & 4 \\
\hline 2 & Katsuura 1, Chiba & Jun. 14, 2012 & 8 \\
\hline 3 & Katsuura 2, Chiba & Jun. 14, 2012 & 4 \\
\hline 4 & Katsuura 3, Chiba & Aug. 22, 2012 & 4 \\
\hline 5 & Isumi A, Chiba & Jun. 21, 2012 & 4 \\
\hline 6 & Isumi B, Chiba & Jun. 26, 2012 & 8 \\
\hline 7 & Mobara, Chiba & Oct. 26, 2012 & 4 \\
\hline 8 & Nagara, Chiba* & Jan. 28, 2013 & 4 \\
\hline 9 & Namegawa, Saitama & 2003 & 5 \\
\hline 10 & Small pond near Yokohama* & 2003 year class & 3 \\
\hline 11 & South-east Tochigi & 2006 & 3 \\
\hline 12 & North Tochigi & $1993-1994$ & 3 \\
\hline 13 & Handa natural habitat conservation area, Tochigi & 1993 & 3 \\
\hline 14 & Central Chiba** & May 16, 2010 & 2 \\
\hline 15 & North Chiba** & Jun. 3, 2010, Jul. 25, 2011 & 16 \\
\hline 16 & Ibaraki A* & Nov. 6, 2014 & 1 \\
\hline 17 & Ibaraki B* & 2014 & 3 \\
\hline 18 & Seized from a home aquarium & 2014 & \\
\hline
\end{tabular}

* Preserved stock ex situ (extinct in the wild).

** Newly found stocks. 
(GATCTTCGGATTACAAGACCGAT) which worked for amplifying a $1219 \mathrm{bp}$ mitochondrial DNA fragment encompassing the whole cytochrome $b$ gene and flanking tRNA partial sequences. PCR reaction mixture of $12.5 \mu \mathrm{L}$ contained $1 \mu \mathrm{L}$ of template DNA, $0.96 \mu \mathrm{L}$ of dNTP mix (2.5 nmol each), $1.2 \mu \mathrm{L}$ of $10 \mathrm{x}$ ExTaq buffer, $0.06 \mu \mathrm{L}(0.3 \mathrm{U})$ of ExTaq (Takara, Shiga, Japan), $1 \mu \mathrm{L}$ of primers (5 pmol each), $7.28 \mu \mathrm{L}$ of Milli-Q grade water. PCR reaction was of touchdown profile (Don et al. 1991 ) in which annealing temperatures dropped from $59^{\circ} \mathrm{C}$ down to $53^{\circ} \mathrm{C}$ in the initial 7 cycles and was constant at $55^{\circ} \mathrm{C}$ in the remaining 28 cycles $(35$ cycles in total). The PCR reaction started with $3 \mathrm{~min}$ at $94^{\circ} \mathrm{C}$ followed by 35 cycles of $30 \mathrm{sec}$ at $94^{\circ} \mathrm{C}$, $30 \mathrm{sec}$ at the above touchdown annealing temperatures, $120 \mathrm{sec}$ at $72^{\circ} \mathrm{C}$ with final extension at $72^{\circ} \mathrm{C}$ for $5 \mathrm{~min}$. The PCR primers and two internal primers (L15438 [TTTTCCTACAAAGATCTATTAGG] and H15569 [CGTAAGATGGCGTAGGCAAATAA] on the L- and $\mathrm{H}$-strand, respectively) worked for overlapping doublestranded sequencing with BigDye terminator v.3.1 kit run on an ABI3730 sequencer (ABI, Foster City CA, USA). The complete mitochondrial cytochrome b sequences used in this research have DDBJ/GenBank entries of LC17598-LC170677.

Indices of nucleotide divergence were calculated with Arlequin v.3.5 (Excoffier and Lischer 2010). Geographic population structure was assessed with SAMOVA v.2.0 (Dupanloup et al. 2002). The net nucleotide divergence was calculated by $\pi_{\mathrm{xy}}-\left(\pi_{\mathrm{x}}+\pi_{\mathrm{y}}\right) / 2$ where $\pi_{\mathrm{xy}}$ is average number of nucleotide differences between populations $\mathrm{x}$ and $\mathrm{y}$, and $\pi_{\mathrm{x}}$ and $\pi_{\mathrm{y}}$ stand for this value between individuals within populations $\mathrm{x}$ and $\mathrm{y}$. Parsimonious haplotype network was drawn with TCS v.1.2.1 (Clement et al. 2000).

\section{Results}

\section{Haplotype grouping}

Sequencing Pseudorhodeus tanago mitochondrial cytochrome b revealed 10 haplotypes (Table 2, Hap01-10). There were 19 variable sites, and 14 nucleotide substitutions observed between the most distant haplotypes (Hap01, 10) (Table 3). All the observed nucleotide substitutions were transitions, two of which were non-synonymous (positions 15100 and 15415). Most specimens from known localities (11/13) were monotypic, whereas newly found and seized stocks except for \#17 with a single individual examined were polymorphic.

A haplotype network coincides with geographically structured population genetic characteristics of this species (Fig. 2). Regarding 13 known localities, haplotypes from each locality frequently were specific to that locality $(9 / 13)$. Haplotypes placed on the upper-left side of the figure (Hap09, 10) were from northern part of the geographic range (Fig. 1b, \#12, 13). Likewise, haplotypes arranged on the right side (Hap01-05) were all from the southern part (Fig. 1b, \#1-6), and Hap08 on the lower-left side of the network was from the western part (Fig. 1b, \#10) of the range. Placement of the other two haplotypes (Hap06, 07) was on the center of the network, and their geo- 
Table 2. Haplotype composition of localities.

\begin{tabular}{l|c|c|c|c|c|c|c|c|c|c}
\hline \# \ Haplotype & Hap01 & Hap02 & Hap03 & Hap04 & Hap05 & Hap06 & Hap07 & Hap08 & Hap09 & Hap10 \\
\hline 1 & 4 & & & & & & & & & \\
\hline 2 & & & & & 8 & & & & & \\
\hline 3 & 4 & & & & & & & & & \\
\hline 4 & & 4 & & & & & & & & \\
\hline 5 & & & 2 & 2 & & & & & & \\
\hline 7 & 7 & & & & & 1 & & & & \\
\hline $8^{*}$ & & & & & & 4 & & & & \\
\hline 9 & & & & & & 4 & & & & \\
\hline $10^{*}$ & & & & & & & 5 & & & \\
\hline 11 & & & & & & & & 3 & & \\
\hline 12 & & & & & & & & & 1 & \\
\hline 13 & & & & & & & & & & 3 \\
\hline $14^{* *}$ & 1 & 1 & & & & & & & & \\
\hline $15^{* *}$ & 8 & 5 & & 3 & & & & & & \\
\hline $16^{* *}$ & & & & 1 & & & & & & \\
\hline $17^{* *}$ & 1 & & & 2 & & & & & & \\
\hline 18
\end{tabular}

* Preserved stock ex situ (extinct in the wild).

** Newly found stocks.

graphic placement was roughly the center of the range (Fig. 1b, \#7-9) except for a single exception from locality \#6 in the southern part (Table 2). This haplotype grouping was delineated by gaps with three or more missing haplotypes, whereas one or no gap lay between haplotypes within these groups. Haplotypes of the south group, however, contained distant types (four nucleotide differences at most), and there might be subgrouping among them.

\section{Geographic grouping}

Geographic grouping of localities by AMOVA (SAMOVA) under assumptions of four or five geographic groups was similar to the haplotype grouping based on the haplotype network without geographic information (Table 4, Fig. 3). Values of sum of squares and coverage of variation among geographic groups were much higher than those values both among localities within geographic groups and within localities indicating clear geographic structures. The North haplotype group (Hap09, 10) appeared in a North geographic group that consisted of localities \#12, 13. Regarding 13 known habitats, the SAMOVA grouping divided the South haplotype group into two geographic groups (south_1 of localities \#1, 3, 6 and south_2 of \#2, 4, 5). The former consisted predominantly of Hap01 which did not appear among specimens from the latter. The Center $(\# 7-9,11)$ and the West (\#10) geographic groups under 


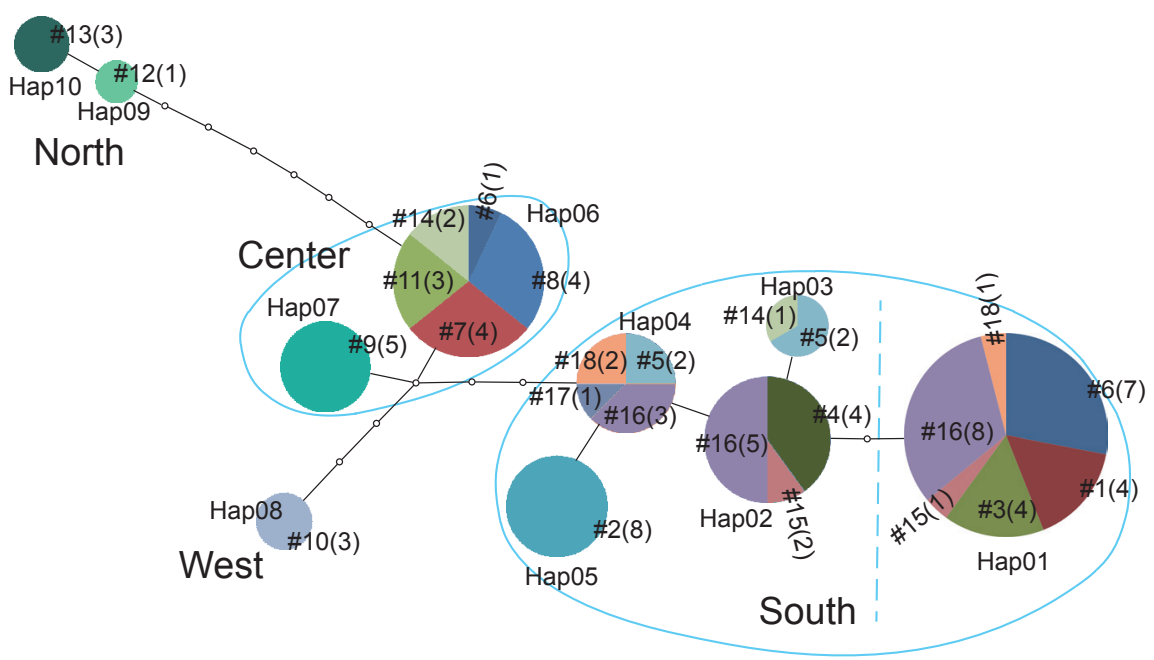

Figure 2. Parsimonious haplotype network of mitochondrial DNA sequences of Pseudorhodeus tanago (Hap01-10). Each line connecting haplotypes indicates one nucleotide difference. Small open circles stand for missing haplotypes. Locality number (\#) and number of individuals observed (parentheses) indicate haplotype sharing. Blue solid lines encircle haplotype groups (north, center, west and south). Blue broken line indicates sub-grouping within the south haplotype group exhibited by SAMOVA analysis (right, south_1; left, south_2).

Table 3. Haplotypes and variable sites of Pseudorhodeus tanago mitochondrial cytochrome b.

\begin{tabular}{|c|c|c|c|c|c|c|c|c|c|c|c|c|c|c|c|c|c|c|c|}
\hline \multirow{5}{*}{ Nucleotide site * } & 1 & 1 & 1 & 1 & 1 & 1 & 1 & 1 & 1 & 1 & 1 & 1 & 1 & 1 & 1 & 1 & 1 & 1 & 1 \\
\hline & 4 & 4 & 4 & 4 & 4 & 4 & 4 & 4 & 4 & 4 & 4 & 5 & 5 & 5 & 5 & 5 & 5 & 5 & 5 \\
\hline & 4 & 4 & 5 & 5 & 5 & 5 & 8 & 9 & 9 & 9 & 9 & 0 & 1 & 2 & 3 & 4 & 4 & 4 & 5 \\
\hline & 1 & 7 & 2 & 2 & 2 & 8 & 0 & 3 & 5 & 6 & 9 & 3 & 0 & 2 & 0 & 1 & 3 & 4 & 1 \\
\hline & 2 & 2 & 0 & 6 & 9 & 0 & 7 & 7 & 5 & 7 & 4 & 0 & $\begin{array}{c}0 \\
* *\end{array}$ & 8 & 1 & $\begin{array}{c}5 \\
* *\end{array}$ & 2 & 7 & 3 \\
\hline Hap01 & $\mathrm{T}$ & G & A & $\mathrm{C}$ & G & G & G & $\mathrm{C}$ & G & $\mathrm{G}$ & G & $\mathrm{T}$ & A & A & $\mathrm{T}$ & G & C & A & $\mathrm{G}$ \\
\hline Hap02 & $\mathrm{T}$ & G & A & $\mathrm{C}$ & G & G & $\mathrm{A}$ & $\mathrm{C}$ & G & G & G & $\mathrm{C}$ & A & A & $\mathrm{T}$ & G & $\mathrm{C}$ & A & G \\
\hline Hap03 & $\mathrm{T}$ & G & A & $\mathrm{C}$ & G & G & $\mathrm{A}$ & $\mathrm{C}$ & G & G & G & $\mathrm{C}$ & A & G & $\mathrm{T}$ & G & $\mathrm{C}$ & A & G \\
\hline Hap04 & $\mathrm{T}$ & G & A & $\mathrm{C}$ & G & G & $\mathrm{A}$ & $\mathrm{C}$ & G & G & G & $\mathrm{C}$ & A & A & $\mathrm{T}$ & G & $\mathrm{T}$ & $\mathrm{A}$ & $\mathrm{G}$ \\
\hline Hap05 & $\mathrm{T}$ & $G$ & A & C & $G$ & $G$ & A & $\mathrm{C}$ & G & $\mathrm{G}$ & $G$ & C & A & A & $\mathrm{T}$ & A & $\mathrm{T}$ & A & G \\
\hline Hap06 & $\mathrm{T}$ & A & A & $\mathrm{T}$ & $\mathrm{G}$ & G & $\mathrm{A}$ & $\mathrm{C}$ & G & $\mathrm{C}$ & A & $\mathrm{C}$ & A & A & $\mathrm{T}$ & G & $\mathrm{T}$ & A & G \\
\hline Hap07 & $\mathrm{T}$ & $\mathrm{A}$ & A & $\mathrm{T}$ & G & G & A & $\mathrm{C}$ & G & G & A & $\mathrm{C}$ & A & A & $\mathrm{C}$ & G & $\mathrm{T}$ & $\mathrm{A}$ & $\mathrm{G}$ \\
\hline Hap08 & $\mathrm{T}$ & A & A & $\mathrm{T}$ & $\mathrm{G}$ & $\mathrm{A}$ & $\mathrm{A}$ & $\mathrm{T}$ & G & $\mathrm{G}$ & A & $\mathrm{C}$ & A & A & $\mathrm{T}$ & $\mathrm{G}$ & $\mathrm{T}$ & $\mathrm{G}$ & G \\
\hline Hap09 & C & A & G & $\mathrm{T}$ & A & G & A & $\mathrm{C}$ & A & A & A & $\mathrm{C}$ & G & A & $\mathrm{T}$ & G & $\mathrm{T}$ & A & A \\
\hline Hap10 & $\mathrm{C}$ & A & G & $\mathrm{T}$ & A & $G$ & $\mathrm{~A}$ & C & $\mathrm{A}$ & $\mathrm{A}$ & $\mathrm{A}$ & $\mathrm{C}$ & $\mathrm{G}$ & A & $\mathrm{T}$ & G & $\mathrm{T}$ & $\mathrm{G}$ & A \\
\hline
\end{tabular}

* Positions corresponding with those of AP012526 (Miya et al. 2015).

** Nucleotide sites with non-synonymous substitutions.

an assumption of five groups coincided with those of haplotype groups, but they were combined under a four groups assumption. Small but clear-cut nucleotide differences between localities within the south haplotype groups in spite of geographic proximity 


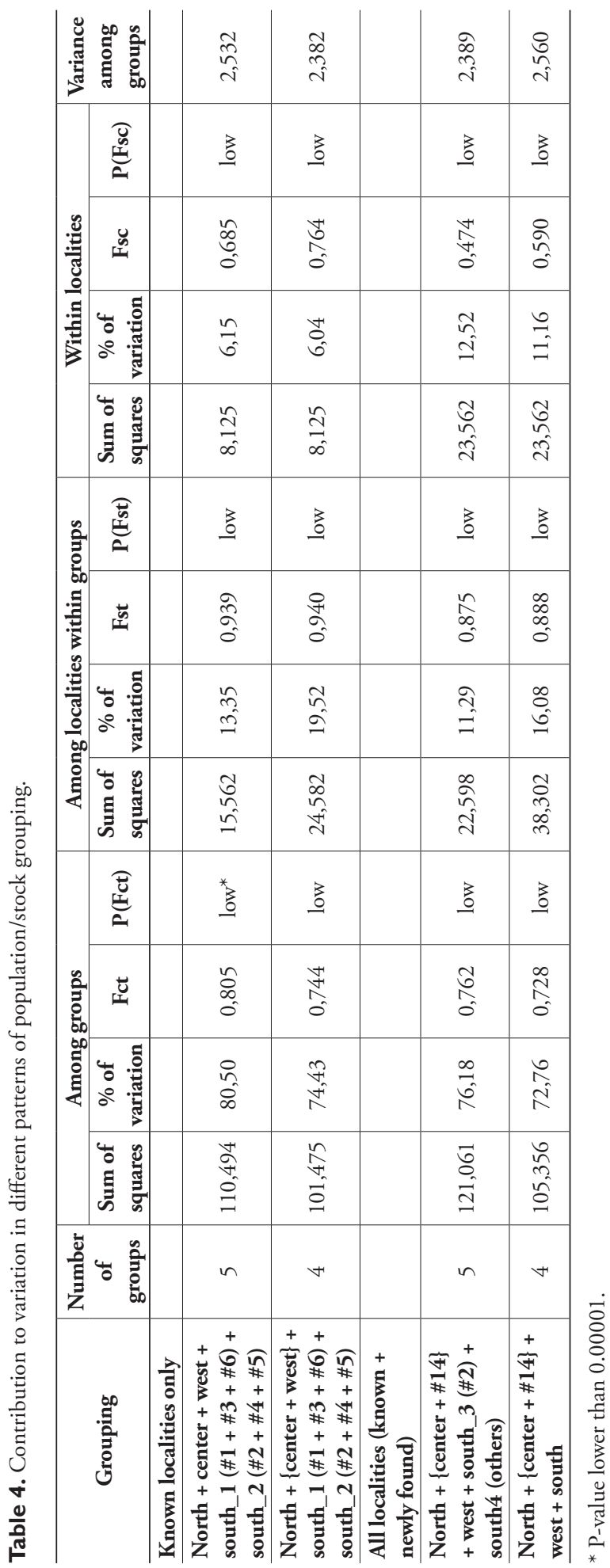




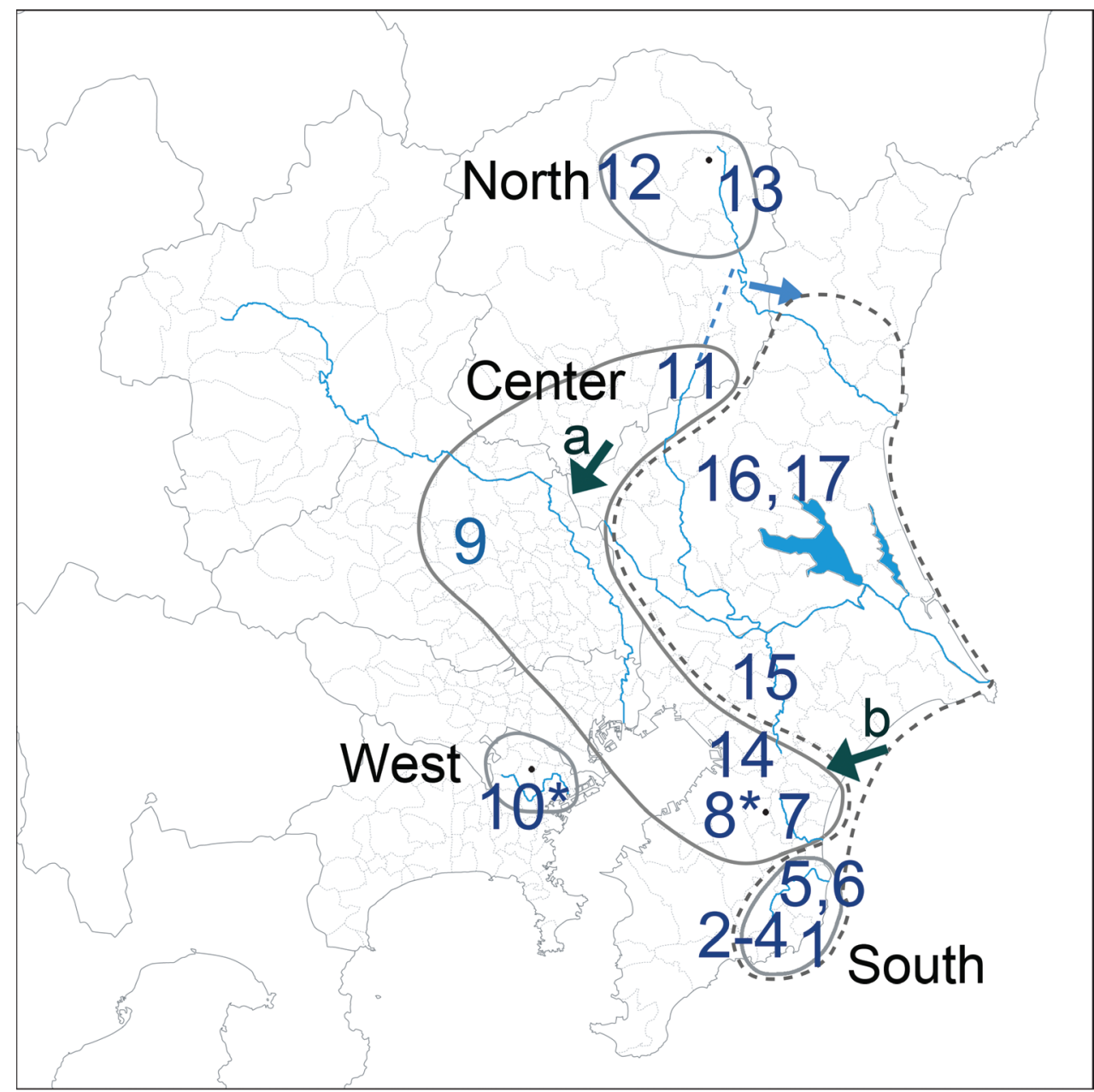

Figure 3. Geographic grouping of localities (encircled by gray solid lines) and river connectivity in 16th century (blue solid lines). Gray broken line encircles localities with the South geographic group including newly found localities (\#15-17). Another newly found locality (\#14) could be a member of the Center geographic group, but its haplotype composition is not typical among localities of the group. Arrows a and $\mathrm{b}$ denote historical overflow or stream capture terrains between river basins. Blue broken line indicates ancient river flow, and a blue arrow denotes change of the river flow at $500 \mathrm{ka}$.

(ca. 1-16 km, Table 5) divided the southern localities into two geographic groups, whereas moderate differences ( 0 to four base changes) among localities of the center and west geographic groups distant from each other (ca. 60-100 km except between \#7 and \#8) could be pooled.

Geographic grouping of known localities was largely coincident with river connectivity (Fig. 3). The North and the West geographic groups appeared each in a single river basin respectively. The South geographic group covered two river basins close to each other, one of which is kept secret by the authority (not shown on the map). 


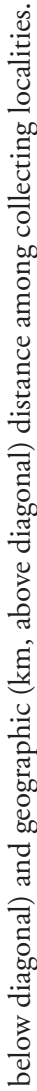

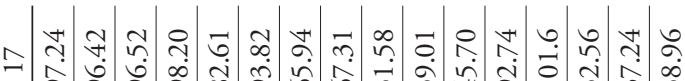
人̃

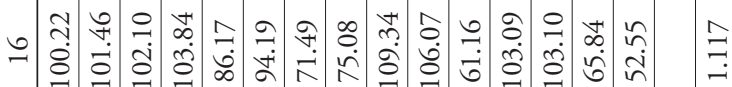

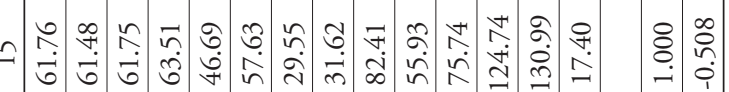

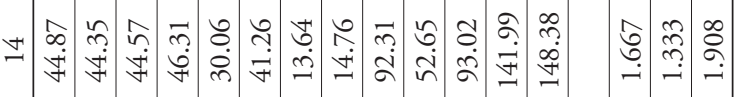

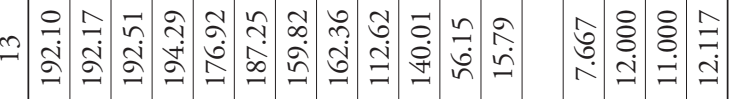

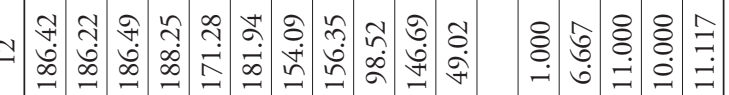

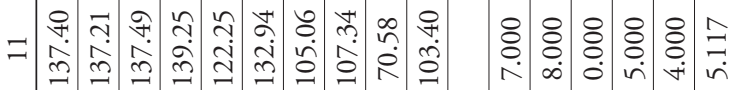

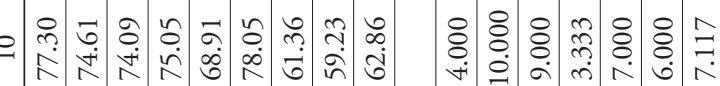

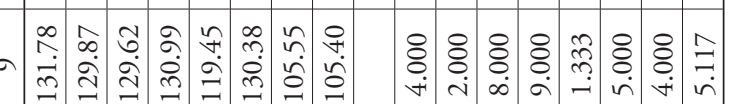

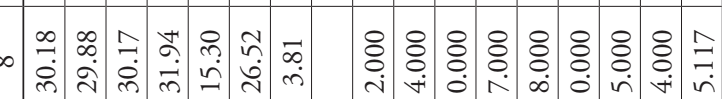

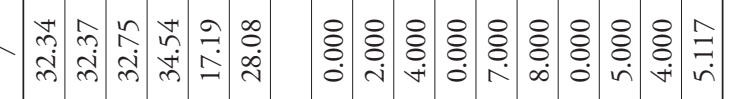

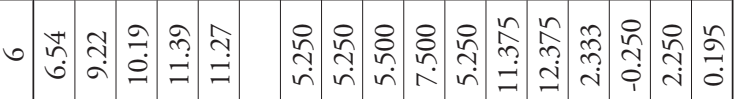

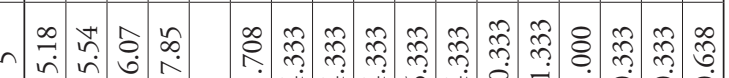

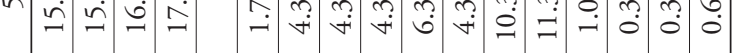

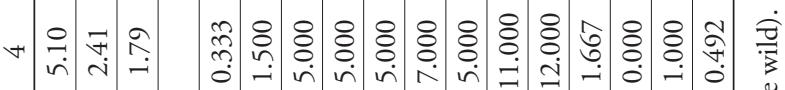

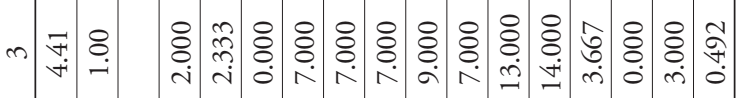

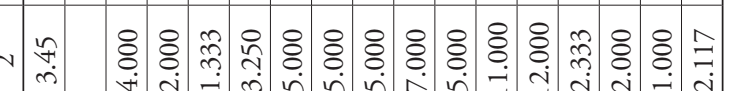
- $\quad$ \& $\frac{n}{3}$

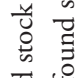

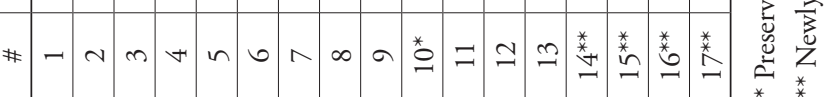


Potential connection between these two basins through deltas is possible. The Center geographic group spanned a wider range on the periphery of a lowland plain which roughly corresponds with the area encircled by the gray solid line of this group plus coastal area on the east (Fig. 3). Localities of this geographic group presented in three river basins potentially connected with each other through flat low overflow terrain of $12 \mathrm{~m}$ high (Fig. 3, arrow a) or overflow plus switching dales (Kagose 1979) (flat hill top at $90 \mathrm{~m}$ high and opposing headwaters with imbalanced slopes at $60 \mathrm{~m}$ high, arrow b).

On the other hand, placement of specimens from newly found localities onto the haplotype network obscured the geographic population genetic structure, though SAMOVA analysis apportioned these localities to either of the South or Center geographic groups according to their haplotype composition. Coverage of variation among geographic groups reduced from 74.43-80.5\% to 72.76-76.18\% (Table 4). Newly found localities except for \#14 contained haplotypes of only the South group in spite of potential river connectivity with localities with the Center or the North geographic groups (Fig. 3). Locality \#14 showed a mixed composition of both the Center and the South haplotype groups.

\section{Discussion}

\section{Genetic architecture of known populations}

The low sequence diversity of Pseudorhodeus tanago represented as monotypy in most known localities (11/13) conformed to their habitat characteristics (Table 2). Specific haplotypes from many of the known localities (9/13) indicated that populations of $P$. tanago rarely exchange with each other. Confinement in small isolated water bodies and subsequent bottleneck events might have brought about the present genetic structure of populations.

Isolation on a wider and geological scale is also responsible for divergence among geographic groups. The North geographic group contained haplotypes distant from others (Hap01 and Hap10), and ancestors of the North and other geographic groups thus diverged first. The central part of the entire geographic range of $P$. tanago encircled the flat plain that underwent repeated marine transgressions (Fig. 3). Marine transgression at $>400 \mathrm{ka}$ (Sugai et al. 2013) and/or change of river flow at $500 \mathrm{ka}$ (Fig. 3, blue arrow) (Koike et al. 1985, Kubota et al. 2010) might be responsible for the isolation of these geographic groups. Repeated marine transgressions afterward have facilitated further isolation among geographic groups.

\section{Implication of genetic characteristics of newly found stocks}

Polymorphism and haplotype composition among newly found stocks, on the other hand, posed a question about the characteristics of genetic and geographic population 
structure of $P$. tanago. If we assume historical basis of distribution and genetic characteristics of these newly found stocks, it must be a series of unlikely geological events and haplotype sorting.

Including these newly found stocks, $P$. tanago as a whole showed a bipartite population structure in which some localities show genetic variation while others rarely do so (Table 2). We should assume population admixture and rampant migration among these newly found stocks or one way migration from northwest part of the map including known populations (Fig. 1a), whereas known populations underwent isolation and bottleneck events. Marine transductions were, however, more frequent near the east coast since geological ancient until historic medieval times where newly found stocks inhabit (Kubo 2007, Sugai et al. 2013), and thus habitats of newly found stocks might be ephemeral prone to bottleneck. River connectivity implies that the hypothetical migration was from central or north geographic group (Fig. 3), but newly found localities (\#15-17) consisted solely of south haplotype group. Admixture between populations around south group of known and newly found localities upon ace age marine regression is unlikely because of absence of continental shelf at the south-east coast (Sugai et al. 2013). Even if it was possible, river connection should involve localities of center geographic group $(\# 7,8)$ (Fig. 3), the main haplotype of which is absent from the newly found localities. Among newly found stocks, \#14 consisted of haplotype of center group and was close to populations of center geographic group $(\# 7,8)$, but its natural distribution is questionable because of disturbance of the habitat by civil engineering. Straight cut channelization with concrete enforcement both on the banks and bottom has eliminated mud-sandy substrates for bitterlings' spawning host mussels.

There is no information such as confession or witness of violators about unauthorized releasing of $P$. tanago into the newly found localities. Genetic polymorphism of newly found localities may arrange stocks of these localities as conservation target of higher priority, if habitats are under risks of extinction. Recent decline of habitats indicates mitigation activities have not worked well (Mochizuki 1997, Ishinabe 2014) or just under trials (Tsunagawa et al. 2016). Then, ex situ breeding which works currently (Kubota et al. 2010, Ishinabe 2014) would be an interim choice. Under the assumption of natural distribution, stocks from newly found localities would be of higher priority for ex situ preservation.

Natural distribution in these newly found localities is, however, questionable because of unlikely association between haplotype/population relationships and river connectivity. Because bitterling fishes have attractive coloration to humans, there have been reports on unauthorized intentional releasing activities possibly implicated in home aquaria (Miyake et al. 2011, Kitazima et al. 2015, Saitoh et al. 2016). Under an assumption of unauthorized releasing or dumping of $P$. tanago, we confront difficult issues. Genetic polymorphism of the newly found and seized stocks (Table 2) implied a number of poaching activities. Because violators do not assess stock size of their target fish in the field, poaching would sometimes be devastating. Unauthorized releasing or dumping, if any, also poses problems. Unauthorized releasing of $P$. tanago is illegal, because unauthorized transfer of this legally protected fish is prohibited. Released $P$. 
tanago individuals themselves are, however, legal target of conservation (Ministry of the Environment, Japan 2015). Presence of questionable stocks thus disturbs prioritization of conservation targets under limited funds and human resources. Releasing or dumping onto habitats of natural populations is a direct threat to the integrity of natural properties of $P$. tanago. Our report has cautionary implication to potential violators.

\section{Acknowledgments}

We dedicate this paper to Toshihiro Ishinabe (deceased) (Kannonzaki Nature Museum) and his contributions to conservation of Pseudorhodeus tanago over two decades carrying out habitat monitoring and ex situ breeding. KS, NS and KI conceived this research. KS analyzed data and drafted the manuscript. NS, MO, KI, TS, TM, TT and MT conducted field survey. All authors read, improved and approved the manuscript. This research was financially supported by a Protective Breeding Program of Ministry of the Environment, Japan. Permission for research use of $P$. tanago was provided by Agency for Cultural Affairs and Ministry of the Environment, Japan to NS and KI. We have no financial conflict of interests about contents of this publication. Specimens were collected under a condition in which the authorities expect non-disclosure of exact places of habitats except for a protected and publicly opened locality (\#13). NS and $\mathrm{KI}$ are employees of two of these authorities that do not disclose some localities. Toshihiro Ishinabe, Hitoshi Kubota (Tochigi Prefectural Government), Kouki Kano (Ibaraki University), Masaki Miya (Natural History Museum and Institute, Chiba), Naoyuki Suguro (Kanagawa Prefectural Fisheries Technology Center) and Kazuhiro Umezawa (Saitama Prefectural Government) helped us collecting specimens. Maya Suzuki (Kanto Regional Environment Office, Ministry of the Environment) helped and coordinated field survey and sample collection. Takahiro Ohtsuka (National Research Institute of Fisheries Science) helped us for laboratory works.

\section{References}

Agency of Environment Japan, Ministry of Education Science and Culture Japan, Ministry of Agriculture Forestry and Fisheries Japan, Ministry of Construction Japan (1995) Protective Breeding Program of Tokyo Bitterling, Tanakia tanago. Agency of Environment, Japan, 3 pp. [In Japanese]

Akiyama N, Imai H, Ogasawara Y (1994) Effectiveness of Margaritifera laevis as spawning bed for Tanakia tanago. Aquaculture Science (Suisanzoshoku) 42: 231-238. [In Japanese with English abstract]

Chang C-H, Li F, Shao K-T, Lin Y-S, Morosawa T, Kim S, Koo H, Kim W, Lee J-S, He S, Smith C, Reichard M, Miya M, Sado T, Uehara K, Lavoué S, Chen W-J, Mayden RL (2014) Phylogenetic relationships of Acheilognathidae (Cypriniformes: Cyprinoidea) as revealed from evidence of both nuclear and mitochondrial gene sequence variation: 
Evidence for necessary taxonomic revision in the family and the identification of cryptic species. Molecular Phylogenetics and Evolution 81: 182-194. https://doi.org/10.1016/j. ympev.2014.08.026

Clement M, Posada D, Crandall K(2000) TCS: a computer program to estimate gene genealogies. Molecular Ecology 9:1657-1660. https://doi.org/10.1046/j.1365-294x.2000.01020.x

Don R, Cox P, Wainwright B, Baker K, Mattick J (1991) 'Touchdown' PCR to circumvent spurious priming during gene amplification. Nucleic Acids Research 19: 4008. https://doi. org/10.1093/nar/19.14.4008

Dupanloup I, Schneider S, Excoffier L. (2002) A simulated annealing approach to define the genetic structure of populations. Molecular Ecology 11: 2571-2581. https://doi. org/10.1046/j.1365-294X.2002.01650.x

Excoffier L, Lischer HEL (2010) Arlequin suite ver 3.5: A new series of programs to perform population genetics analyses under Linux and Windows. Molecular Ecology Resources 10: 564-567. https://doi.org/10.1111/j.1755-0998.2010.02847.x

Fuller P, Neilson M, Huge DH (2013) The NAS alert system: A look at the first eight years. Fisheries 38: 128-138. https://doi.org/10.1080/03632415.2013.767241

Gertzen E, Familiar O, Leung B (2008) Quantifying invasion pathways: fish introductions from the aquarium trade. Canadian Journal of Fisheries and Aquatic Sciences 65: 1265-1273. https://doi.org/10.1139/F08-056

Ishikawa T, Tachihara K (2014) Introduction history of non-native freshwater fish in Okinawajima Island: ornamental aquarium fish pose the greatest risk for future invasions. Ichthyological Research 61: 17-26. https://doi.org/10.1007/s10228-013-0367-6

Ishinabe T (2014) Conservation practices of the Tokyo bitterling, Tanakia tanago, in Chiba Prefecture. In: Nagata Y (Ed.) An Introduction to Freshwater Fish Research: Snoop into Fish Life under the Water. Tokai University Press, Hadano, 103-112.

Kagose Y (1979) Stream capture by Konakaike catchment at the edge of Shimousa upland. Chiri (Geography) 24(11): 78-81. [In Japanese]

Kitazima J, Matsuda M, Mori S, Kokita T, Watanabe K (2015) Population structure and cryptic replacement of local populations in the endangered bitterling Acheilognathus cyanostigma. Ichthyological Research 62: 122-130. https://doi.org/10.1007/s10228-014-0412-0

Kobori H, Primack RB (2003) Participatory conservation approaches for satoyama, the traditional forest and agricultural landscape of Japan. AMBIO: A Journal of the Human Environment 32: 307-311. https://doi.org/10.1579/0044-7447-32.4.307

Koike K, Iwasaki T, Danbara T, Momose M (1985) Fission-track ages and their geological meanings of quaternary volcanic ashes (Shimotsuke-loam) covering the Kitsuregawa Hills, Tochigi Prefecture, central Japan. Science Reports of Geographical Institute, Komazawa University 21: 39-67. [In Japanese]

Kubo S (2007) Joso Inland Sea: Topography and environmental changes of Katori Plain in historic times. In: Ichimura T, Ibaraki Prefectural Museum of History (Eds) Outlook of Inland Seas in Medieval East Japan. Koshi Shoin, Tokyo, 39-64. [In Japanese]

Kubota H, Watanabe K, Suguro N, Tabe M, Umezawa K, Watanabe S (2010) Genetic population structure and management units of the endangered Tokyo bitterling, Tanakia tanago (Cyprinidae). Conservation Genetics 11: 2343-2355. https://doi.org/10.1007/s10592-010-0120-x 
Lintermans M (2004) Human-assisted dispersal of alien freshwater fish in Australia. New Zealand Journal of Marine and Freshwater Research 38: 481-501. https://doi.org/10.1080/0 0288330.2004 .9517255

Maita A (2002) The study of social management systems for conservation of miyakotanago habitats in satochi. Bulletin of the Tokyo University Forests 107: 127-223. [In Japanese with English summary]

Ministry of the Environment, Japan (Ed.) (2015) Red Data Book 2014 - Threatened Wildlife of Japan - Vol.4 Pisces - Brackish and Fresh Water Fishes. Gyosei, Tokyo, 414 pp. [In Japanese]

Miya M, Sato Y, Fukunaga T, Sado T, Poulsen JY, Sato K, Minamoto T, Yamamoto S, Yamanaka H, Araki H, Kondoh M, Iwasaki W (2015) MiFish, a set of universal PCR primers for metabarcoding environmental DNA from fishes: detection of more than 230 subtropical marine species. Royal Society Open Science 2: 150088. https://doi.org/10.1098/ rsos. 150088

Miyake T, Nakajima J, Onikura N, Ikemoto S, Iguchi K, Komaru A, Kawamura K (2011) The genetic status of two subspecies of Rhodeus atremius, an endangered bitterling in Japan. Conservation Genetics 12: 383-400. https://doi.org/10.1007/s10592-010-0146-0

Mochizuki K (1997) Tanakia tanago (Tanaka). In: Nagata Y, Hosoya K (Eds) Circumstances in Endangered Japanese Freshwater Fishes and Their Protection. Midori Shobo, Tokyo, 64-75. [In Japanese]

Nakamura M (1969) Cyprinid Fishes of Japan: Studies on the Life History of Cyprinid Fishes of Japan. Special Publication of the Research Institute for Natural Resources 4, Tokyo, 455 pp. [In Japanese with English summary]

Saitoh K, Shindo K, Fujimoto Y, Takahashi K, Shimada T (2016) Mitochondrial genotyping of an endangered bitterling Acheilognathus typus. ZooKeys 623: 131-141. https://doi. org/10.3897/zookeys.623.8981

Sugai T, Matsushima [Ogami] H, Mizuno K (2013) Last 400 ka landform evolution of the Kanto Plain: Under the influence of concurrent glacio-eustatic sea level changes and tectonic activity. Journal of Geography (Chigaku Zasshi) 122: 921-948. [In Japanese with English abstract] https://doi.org/10.5026/jgeography.122.921

Tanaka S (1909) Descriptions of one new genus and ten new species of Japanese fishes. The Journal of the College of Science, Imperial University of Tokyo, Japan 27: 1-27

Tochigi Prefectural Fisheries Experimental Station (1973) Interim report of research on conservation measures of Tokyo Bitterling and stickleback. Annual Report of the Tochigi Prefectural Fisheries Experimental Station 15: 103. [In Japanese]

Tsunagawa T, Sakai T, Kubota H (2016) Activities for long-term persistence of a wild population of Tokyo Bitterling: An approach to supportive breeding and habitat restoration. In: Nature Conservation Committee of Ichthyological Society of Japan, Watanabe K, Mori S (Eds) The Challenges of Freshwater Fish Conservation: Concepts and Practice for Restoration of Aquatic Biodiversity. Tokai University Press, Hadano, 51-65. [In Japanese]

Waples RS, Gaggiotti O (2006) What is a population? An empirical evaluation of some genetic methods for identifying the number of gene pools and their degree of connectivity. Molecular Ecology 15: 1419-1439. https://doi.org/10.1111/j.1365-294X.2006.02890.x 